MANUELA PINZARI $(*)$ - MARIO PINZARI $(* *)$ - VALERIO SBORDONI $(*)$

\title{
NOTES ON LIFE-HISTORY OF ERYCIA FURIBUNDA (DIPTERA TACHINIDAE), A PARASITOID OF EUPHYDRYAS AURINIA PROVINCIALIS (LEPIDOPTERA NYMPHALIDAE)
}

\author{
(*) Dipartimento di Biologia, Università di Roma Tor Vergata, Via della Ricerca Scientifica, 1 - 00133 Roma (Italy). \\ Corresponding author: e-mail: manuela.pinzari@uniroma2.it \\ ${ }^{(* *)}$ Dipartimento di Ingegneria, Università di Roma 3, Via della Vasca Navale, 79 - 00146 Roma (Italy).
}

Pinzari M., Pinzari M., Sbordoni V. - Notes on life-history of Erycia furibunda (Diptera Tachinidae), a parasitoid of Euphydryas aurinia provincialis (Lepidoptera Nymphalidae)

In this paper we present new data on the larval-pupal parasitoid Erycia furibunda found in association with coexisting populations of $E$. aurinia provincialis in Central Italy. For the first time we provide information on the biology of this tachinid revealing the duration of puparium stage, the protandry and adult phenology in captive conditions.

KEY WoRDS: Erycia furibunda, parasitoid, Euphydryas aurinia provincialis, butterfly, protandry.

\section{INTRODUCTION}

Hymenopterans and Dipterans include parasitoids whose larvae may feed "on", but more often "in" the bodies of other arthropods. They are of immense importance in all ecosystems because they can influence or regulate the population density of many of their hosts including butterflies. Contrarily to the considerable attention paid to European butterflies by collectors and conservationists, their parasitoids have relatively received less attention. While it is relatively straightforward to identify the mortality factors for a host, it is more difficult to estimate the effects of a parasitoid on the dynamics of host populations (abundance of butterflies). To do this it would be necessary to build better knowledge about parasitoids.

Parasitoids may be divided into koinobionts and idiobionts on the basis of whether or not they allow their host to feed and develop beyond the stage attacked (ASKEW \& SHAW, 1986). Koinobionts benefit from the continued life of their hosts and generally show a high degree of host-parasitoid physiological integration during their young larval stages (Beckage, 1985; Pennacchio \& Strand, 2006). Conversely, idiobionts display low physiological interaction with the host, which is permanently paralyzed or killed before the parasitoid egg hatches (DINDO, 2011).

Several families of Diptera behave as parasitoids but only one family, Tachinidae (very occasionally some species of Bombyliidae), includes parasitoids of butterflies. All tachinids attacking butterflies parasitize the larval stage, though some do not kill the host until it has pupated. They employ a wide variety of strategies to get their larvae into the host. All tachinids are endoparasitoids and are usually considered as koinobionts, as none of them kills or paralyzes the host when first entering it, according to the classification proposed by ASKEW \& SHAW (1986). However, tachinids fit rather poorly into the koinobiont/idiobiont dichotomy described originally for $\mathrm{Hy}-$ menopteran parasitoids because few species show a high degree of physiological adaptation to the host; in other species the larvae grow quickly and kill the host rapidly, thus behaving more as idiobionts (BELSHAW, 1993; DINDO, 2011).
Most parasitoids attack their hosts at a fairly precise lifehistory stage and can be categorized in egg, larval and pupal parasitoids. Hymenopterans that parasitize butterflies can attack egg (Chalcidoidea and Platygastroidea), larval (mainly, Ichneumonoidea) and pupal (some Ichneumonidae and some family of Chalcidoidea) stages. Among Dipterans, several tachinids attacking Lepidoptera parasitize the larval stage and stay inside the host body until it has pupated; for this reason they are also indicated as larval-pupal parasitoids (SHAw et al., 2009).

Tachinidae is one of the largest of approximately 125 families of Diptera in Europe (PAPE et al., 1995). Out of four subfamilies in Europe, three (Dexiinae, Exoristinae and Tachininae), contain parasitoids of Lepidoptera. Only Exoristinae and Tachininae include species that regularly attack butterflies (SHAW et al., 2009).

In Europe four species of genus Erycia RobineauDesvoidy, 1830 (Exoristinae) use Melitaeini butterflies as host [fatua (Meigen 1824), furibunda (Zetterstedt 1844), festinans (Meigen 1824) and fasciata (Villeneuve 1924)]. Among these species, three parasitize the Euphydryas checkerspots: Erycia furibunda is a larval-pupal parasitoid of Euphydryas aurinia (Rottemburg 1775) and all European congeneric species (Ford \& SHAW, 1991; Herting, 1960; Belshaw, 1993; Tschorsnig \& Herting, 1994; Ford et al., 2000; VAN NouHUYS \& HANSKI, 2004; STEFANESCU et al., 2009); Erycia festinans is parasitoid of Euphydryas aurinia (HerTing, 1960), while Erycia fatua is parasitoid of Euphydryas aurinia, and Euphydryas desfontanii (Godart 1819) (PORTER, 1981; VAN NOUHUYS \& HANSKI, 2004).

In Italy, although all four species of genus Erycia are present [Erycia fasciata, in North; E. fatua, in North and South; E. festinans, in South and Sicily (Minelli et al., 1993; Cerretti, 2010); E. furibunda, in North (CERREtTI, 2006) and in Centre (FORD et al., 2000)], only one case of parasitism by Erycia furibunda on Euphydryas aurinia spp. provincialis was recorded in the past (Umbria, FORD et al., 2000). Moreover, during our previous field-work on larval stages of E. a. provincialis in Central Apennines (PINZARI et 
al., 2016) we recorded the tachinid Erycia furibunda on larval nests of the butterfly.

Erycia furibunda has been little studied so far and its biology is poorly known; existing observations report adults feeding on flowers of Laserpitium L. and Heracleum L. (TsCHORSNIG et al., 2003). It is also recorded that males exhibit the hilltopping strategy to encounter females grouping on a mountain peak and sitting on stones (TsCHORSNIG, 1996). Yet data on parasitism of E. aurinia are rather scanty (SFORZA, 2003; STEFANESCU et al., 2009).

Here, we report our observations concerning the occurrence of Erycia furibunda as a larval-pupal parasitoid of the butterfly Euphydryas aurinia spp. provincialis in Central Italy and describe for the first time some aspects of the parasitoid biology.

\section{MATERIALS AND METHODS}

Host OF E. FURIBUNDA

As far as we know, the reported hosts of E. furibunda are Euphydryas aurinia (Fig. I, 1) and most of other congeneric species in Europe (SHAw et al., 2009).

A population of $E$. aurinia provincialis was first reported by PINZARI et al. (2010) in a checklist of lepidoptera in the area of Vallemare (Rieti, Lazio, Central Italy, Location WGS84: N42.4836 $-\mathrm{E} 13.1148^{\circ}$ ). In this area, the species inhabits habitat patches in montane grassland and slopes at $1000 \mathrm{~m}$ within a mosaic of different habitats including wooded areas, hedgerows and fields. Females oviposit on the plants Gentiana cruciata L., Scabiosa columbaria L. and Cephalaria leucantha (L.) Roem. \& Schult., and caterpillars feed on these host plants including also Lonicera caprifolium L. Larval development includes six instar stages, three before and three after diapause in the winter. The first three stages are gregarious and the caterpillars grow inside a silk nest from May to September (Fig. I, 2). They moult from the third to fourth instar inside a winter nest from which they go out in February of the following year. The fourth instar larvae are still gregarious although not inside a silk nest; the fifth and sixth instar larvae are solitary. The pupal stage occurs in April and the adult emergence starts in May (PINZARI et al., 2016).

\section{SAMPLING OF ERYCIA FURIBUNDA}

In 2015 we recorded three flies of Erycia furibunda by photographs on larval nests of $E$. a. provincialis and also collected five adults with a butterfly net. Specimens of $E$. furibunda were identified by their habitus (TsCHORSNIG \& Herting, 1994). P. Cerretti (Rome, Italy) confirmed identification and helped in sexing of individuals. These specimens are presently preserved in Mario Pinzari Collection in Rome (Italy).

\section{SAMPLING OF E. A. PROVINCIALIS LARVAE}

The larvae were collected in 2015 and 2016 through a wide area (then, they are not from the same larval nest) within the habitat patch n. 4 nearby the Crossroads Santa Maria del Monte - Fonte Brignola (see the location in
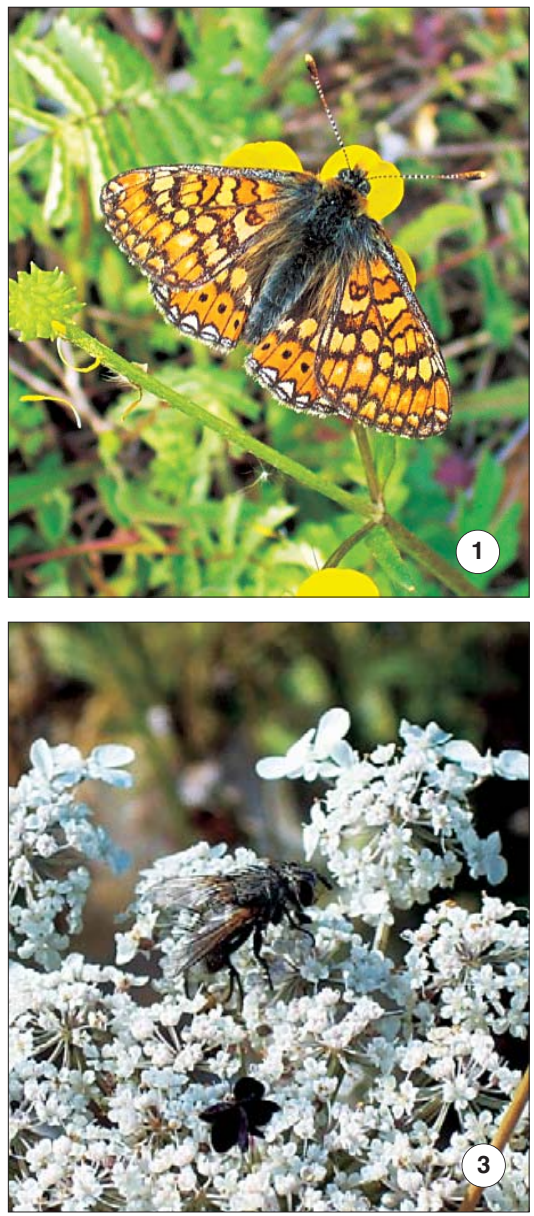
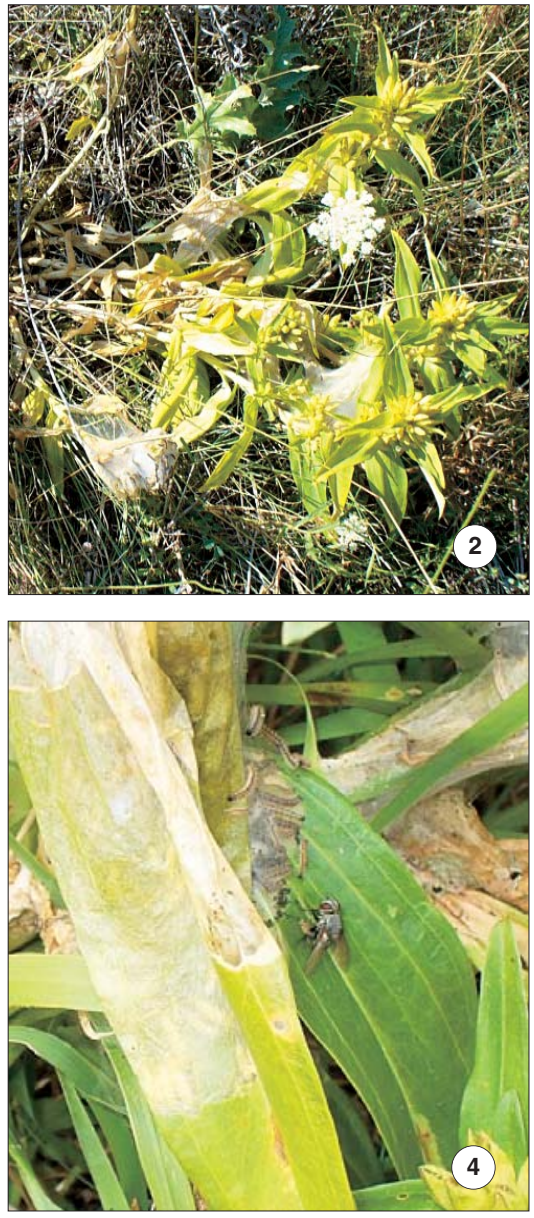

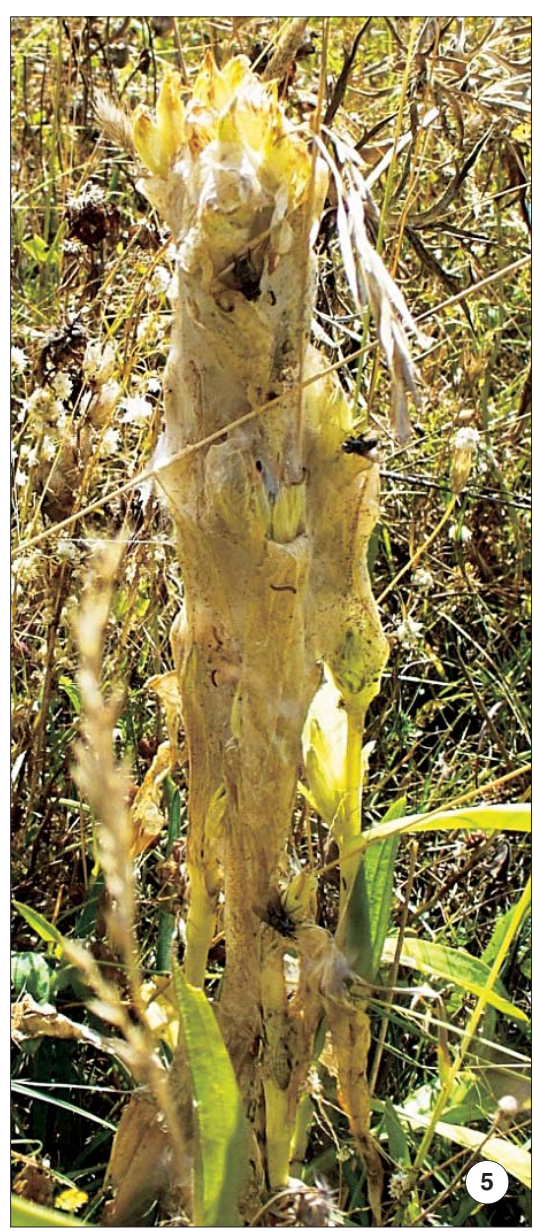

Fig. I - 1, adult of E. a. provincialis; 2, larval pre-diapause nest of $E$. a. provincialis on the hostplant Gentiana cruciata; 3 , adult of $E$. furibunda while feeds on Daucus carota; 4, female of Erycia furibunda while oviposits nearby the caterpillars of E. a. provincialis (August 2, 2015); 5, three females of E. furibunda that are present simultaneously on the nest of E. a. provincialis on Gentiana cruciata. 
PINZARI et al., 2016). The sampling area corresponds to montane grassland habitats and slopes, sometimes steep and rocky, on calcareous soils, which were deeply exploited in the past for grazing but nowadays suffer from a much weaker pressure by cattle and sheep.

In 2015 , twenty-eight $\mathrm{V}$ instar larvae were collected in this site; in 2016, they were fifty. These larvae were reared inside bio boxes (i.e. wood-framed cages with netted sides, $30 \times 15 \times 15 \mathrm{~cm}$,) in laboratory in Rome at environmental conditions (ca. $20-22^{\circ} \mathrm{C}$; $45-60 \%$ relative humidity; normal photoperiod, 12-hour light-dark cycle). Until pupation and fed mainly with leaves of Lonicera caprifolium L. and Scabiosa columbaria L.

\section{REARING OF E. FURIBUNDA}

In order to investigate the life history of E. furibunda, we started from the parasitized pupae.

A parasitized pupa was identified by its change in colour from the whitish typical colour to reddish and later to dark brown; this corresponds to the outcoming time of the maggots (Fig. II, 1, 2 and 3) or also the death of pupa for unknown reasons. On the contrary, when the pupa is parasite-free it maintains its typical whitish colour and becomes transparent when the adults of E. a. provincialis emerge. The reddish pupae were isolated and labelled; then, when the maggots left the pupae, the puparia were individually kept in separate small cardboard boxes $(3 \times 3 \times 3$ $\mathrm{cm}$, with one open netted side) until the fly emergence. Pupae were monitored at two fixed times, 7 AM and 7 PM, and also randomly on night and day. For each individual we recorded time and date of the following events: a) the formation of pupa; b) the emergence of parasitoid larva (maggot) from pupa and the formation of the parasitoid puparium; c) the break of puparium and the emergence of the adult of $E$. furibunda.

We measure the duration of the development of the tachinid larva up to its puparium. This was calculated as the time period between the emergence of maggot from pupa and the formation of the pupa occurred .

Moreover, we calculated the rate of parasitism (RP), as the ratio between the number of emerging maggot from butterfly pupae and the total number of pupae (Table 1). Specimens of E. furibunda were sexed after death.

\section{RESULTS}

RECORDS OF E. FURIBUNDA ADULTS IN THE WILD

Collected specimens: 2 q, , Vallemare (RI) S. Maria Incrocio, 1000 m, 2.VIII.2015, 2 우, idem 5.VIII.2015, 1 Q, idem, 7.VIII.2015.

Observations: 6 ex, Vallemare (RI) S. Maria Incrocio, $1000 \mathrm{~m}$, 5.VIII.2015.

Notes. Three individuals were observed on August, 5, rested on larval nest (Fig. I, 5); three adults were observed feeding on Daucus carota L. (Fig. I, 3).

\section{RATE OF PARASITISM OF E. A. PROVINCIALIS - E. FURIBUNDA SYSTEM}

In the study locality, the parasite emerging from $E$. $a$. provincialis larvae was only E. furibunda.

In two years, out of 79 caterpillars of E. a. provincialis, 78 formed the pupae. Only one larva died during rearing for unknown causes. Out of 78 pupae, $73 \%$ became butterflies,
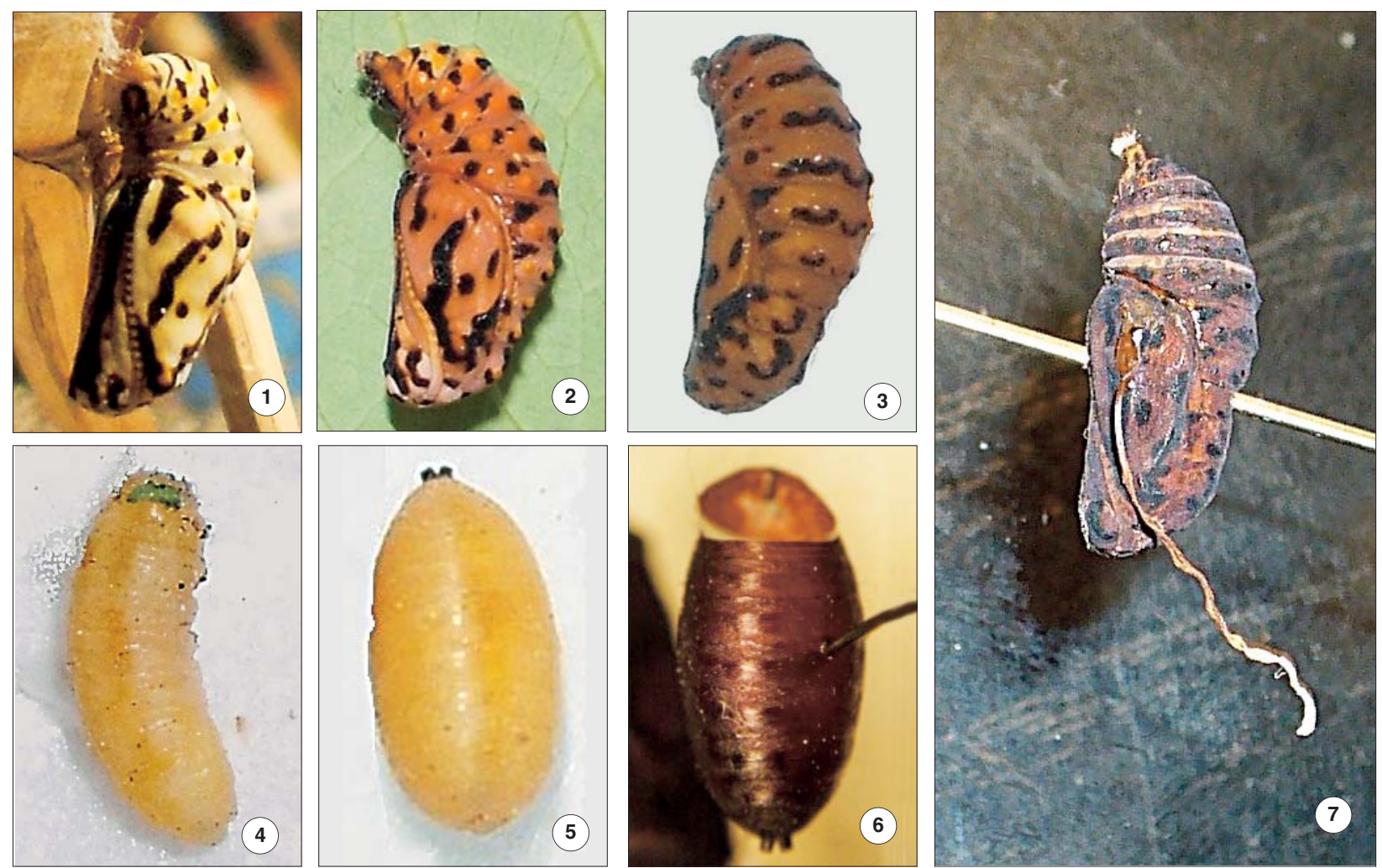

Fig. II - Development of E. furibunda: 1, a newly formed pupa of $E$. a. provincialis; 2, the pupa has changed in colour from whitish to reddish; 3, the pupa varied in colour from reddish to brownish before the maggot coming out; 4, a maggot of E. furibunda (length, $9 \mathrm{~mm}$ ) that just emerged from pupa; 5, a newly formed puparium (length, $7 \mathrm{~mm}$ ); 6 , an exuvia of the puparium after the emergence of adult of E. furibunda; 7, a pupa of E. a. provincialis after the parasitoid emergence with its mucus strand left at the exit site in wingcase of pupa. 
Table 1 - Rearing results and Ratio of parasitism of E. a. provincialis - E. furibunda system.

\begin{tabular}{|c|c|c|c|c|c|c|c|c|c|}
\hline \multirow{3}{*}{ Year } & & \multirow{2}{*}{\multicolumn{4}{|c|}{$\begin{array}{c}\text { Euphydryas aurinia provincialis } \\
\text { Pupae }\end{array}$}} & \multicolumn{4}{|c|}{ Erycia furibunda } \\
\hline & & & & & & \multicolumn{2}{|c|}{ Puparia } & \multicolumn{2}{|c|}{ Adult sex } \\
\hline & & Total & Parasitized (RP)* & Dead & Adult & Dead & Adult & Male & Female \\
\hline \multirow{2}{*}{2015} & $\mathrm{~N}$ & 28 & 1 & 2 & 25 & 0 & 1 & 1 & 0 \\
\hline & $\%$ & 100 & 4 & 7 & 89 & 0 & 100 & 100 & 0 \\
\hline \multirow{4}{*}{2016} & $\mathrm{~N}$ & 50 & 12 & 6 & 32 & 4 & 8 & 5 & 3 \\
\hline & $\%$ & 100 & 24 & 12 & 64 & 38 & 62 & 62 & 38 \\
\hline & N Total & 78 & 13 & 8 & 57 & 4 & 9 & 6 & 3 \\
\hline & \% Total & 100 & 17 & 10 & 73 & 31 & 69 & 67 & 33 \\
\hline
\end{tabular}

*RP, rate of parasitism of the pupae; as concerns puparia, the $\%$ of dead and adults have been calculated on the total of parasitized pupae, while the $\%$ of fly sexes on the total of producing adults.

$10 \%$ died for unknown cause, $17 \%$ died as parasitized (Table 1).

Concerning Erycia 38\% of puparia died for unknown reasons, while the $62 \%$ of them gave rise to eight adults of Erycia furibunda with a male-biased sex ratio (5:3) (Table 1, 2016 data).

The parasitism rate (RP) of the pupae differed in the two years $(2015,4 \% ; 2016,24 \%, p=0.02)$.

\section{NOTES ON THE LIFE HISTORY OF E. FURIBUNDA}

\section{Oviposition in the wild}

Five females of $E$. furibunda were collected from natural population from August 2, 2015, to August 7, 2015 when they rested on larval nest of $E$. a. provincialis on the plant $G$. cruciata; out of these females, a single female was photographed while ovipositing on the larval nest of $E$. $a$. provincialis (Fig. I, 4). Females evert their telescopic ovipositor and insert the oviscapt in the silk of checkerspot larval web nearby the caterpillars or in front of them while they move forward to eat. The actual parasitization event (i.e egg laying or larvae dropping onto host) was never observed. The oviposition occurs when caterpillars of E. a. provincialis are in early stages (I-III instar) before winter diapause.

Phenology of E. furibunda in captivity: larvae, adults and hosts

Parasitized caterpillars of E. a. provincialis normally developed until they became a pupa. At this stage, after the pupa has finished changing in colour (from the whitish typical colour to reddish and later to dark brown, Fig. II, 1, 2 and 3), the maggot of E. furibunda erupted the pupa with a mucus strand (Fig. II, 7); this was produced by maggots when they left the host as observed in other tachinid parasitoids of butterflies (BAUMGART et al., 2003; KAN \& KAN, 2015). From each parasitized pupa a single maggot of E. furibunda emerged by breaking through the wing-case of the pupa. The parasitized pupae were at this stage completely depleted.

E. furibunda completes the larval stage in about three and a half days $(\mathrm{N}=12$, mean $83 \mathrm{~h}$, range: $48-162 \mathrm{~h})$. Males need about three days $(\mathrm{N}=5$, mean $68 \mathrm{~h}$, range $48-96 \mathrm{~h})$ and females about four days $(\mathrm{N}=3$, mean $102 \mathrm{~h}$, range 48 $162 \mathrm{~h}$ ). The time necessary for the development of not sexed individuals (died before adult emergence) was about four days $(\mathrm{N}=4$, mean $88 \mathrm{~h}$, range $60-114 \mathrm{~h})$.
The maggots emerge from pupae over a period of fourteen days (from April 17 to April 30, 2016: five males, 17-22 April; three females, 17-30 April; four individuals, 17-24 April, that were not sexed because died). Note that the male emergence time at maggot stage tends to be shorter (i.e. six days) than females (i.e. fourteen days) (Fig. III). When the maggot leaves the host (Fig. II, 4), it pupates in a puparium (Fig. II, 5, 6).

The time of development from puparium to adult was about 18 days (Fig. IV) $(\mathrm{N}=8$, mean $451 \mathrm{~h}$; range: $378 \mathrm{~h}$ $522 \mathrm{~h})$. Males emerged on average after $412 \mathrm{~h}(\mathrm{~N}=5$, range: $378 \mathrm{~h}-448 \mathrm{~h})$, while females emerged $516 \mathrm{~h}(\mathrm{~N}=3$; range: $507 \mathrm{~h}-522 \mathrm{~h}$ ). The adults emerged from 4 to 21 May 2016. Five males emerged from puparia from 4 to 9 May, while three females from 9 to 21 May. As shown by the phenology of puparia males of E. furibunda emerged through a period (six days) shorter than females (thirteen days).

Butterflies emerged before the parasitoids (Figs. III, IV) from 22 April to 3 May 2016. Males of E. a. provincialis came out from 22 to 30 April and females from 27 April to 3 May showing a protandry according to observations in the wild by the Manuela Pinzari (unpublished data). The reader takes into account that the adult emergence of both butterfly and tachinid was in advance of about 20 days respect the natural phenology in the wild, due to the favourable breeding conditions (mild temperatures, food availability with continuity) for caterpillars and then fly larvae

\section{DISCUSSION}

Efforts for butterfly conservation in Europe have mainly been addressed to safeguard species habitats by means of their quality (host plant abundance, host plant size and vegetation characteristics of host plant cover), environmental variables (soil temperature, air temperature and soil moisture, slope, wind patterns and sun exposure of land), landscape pattern and connectivity (shape and size, presence of corridors) of the sites (KÜHN et al., 2005; NEW, 2013). In line with these topics, Euphydryas butterflies, and in particular Euphydryas aurinia, one of the most threatened butterflies in Europe, have been the subject of much ecological research (EHRLICH \& HANSKI, 2004). In fact, $E$. aurinia is highly selective for both quality and spatial distribution of habitats (KONVICKA et al., 2003; TJøRNLøV et al., 2014) and persists in landscapes via metapopulation dynamics, forming spatially restricted colonies inter- 
Fig. III - Puparia of E. furibunda that emerged daily from parasitized pupae whose larvae of $E$. a. provincialis were collected in 2016 and phenology of $E$. $a$. provincialis adults. In the istogram sexes of parasitoids and its host are shown by $\mathrm{M}$ (males) and $\mathrm{F}$ (females).
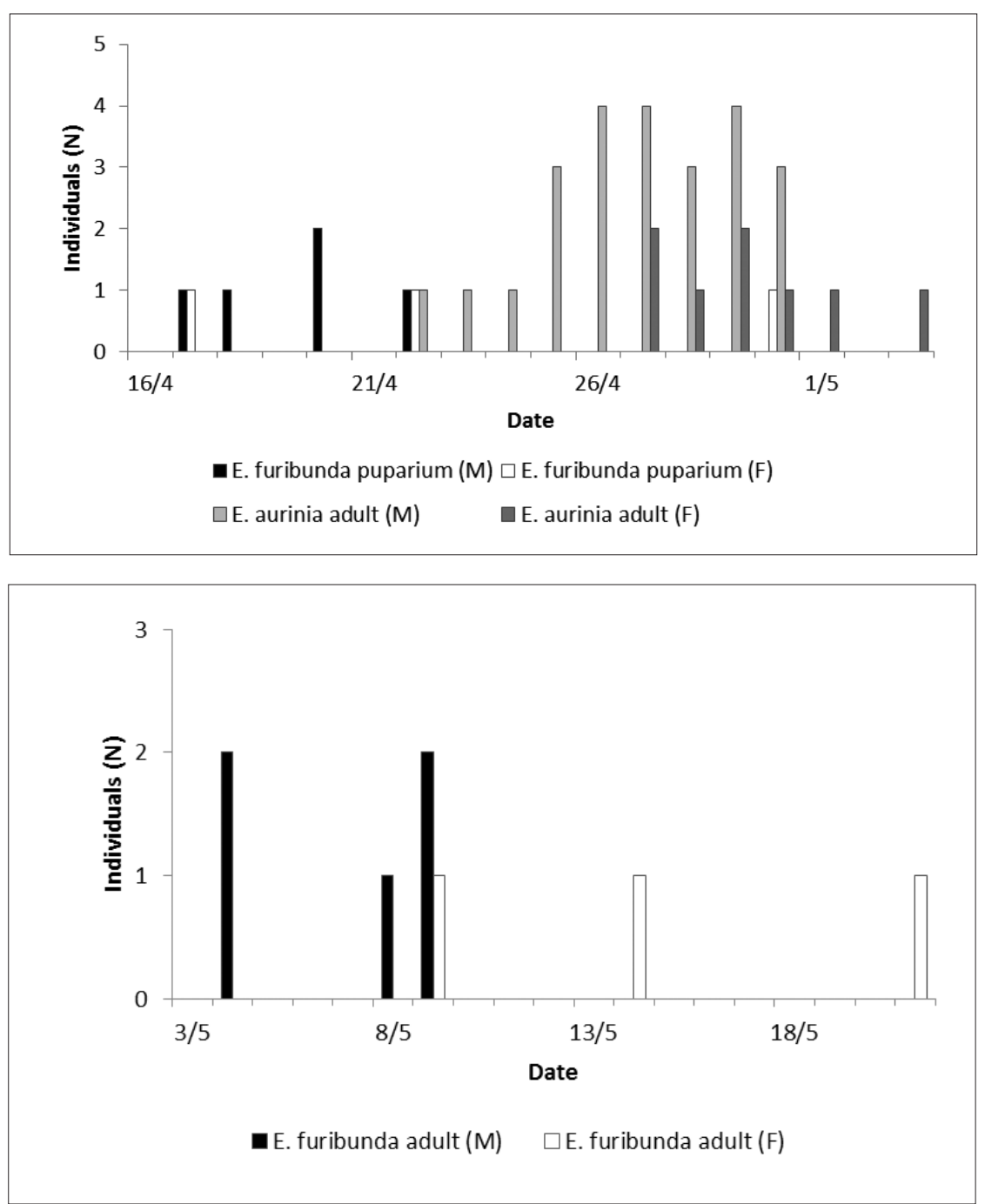

Fig. IV - Phenology of the adults in $E$. furibunda that emerged daily from parasitized pupae whose larvae of $E$. $a$. provincialis were collected in 2016 . The sexes are indicated by $\mathrm{M}$ (males) and $\mathrm{F}$ (females). aurinia provincialis in Central Italy. Our observations revealed E. furibunda as larval-pupal parasitoid of $E$. $a$. provincialis confirming the record by FORD et al. (2000) in Italy. These authors reported only an individual of $E$. furibunda that emerged from a larva of E. a. provincialis collected on Monte Subasio, Umbria. So far, our findings showed no other parasitoids, as those reported in Europe for Euphydryas aurinia and other cogeneric species (VAN NOUHUYS \& HANSKI, 2004; SHAW et al., 2009).

As concerns the observations in the wild we illustrated the female oviposition strategy adopted by E. furibunda. This species oviposits on the larval web of E. aurinia provincialis and nearby eating caterpillars. When the fly egg laying occurs the host was at early larval stages before winter diapause. Then, E. furibunda might adopt an indirect oviposition strategy as observed in other tachinids (CERRETTI et al., 2010; Dindo, 2011). In indirect strategies, eggs may be laid in the immediate vicinity of a host and the newly hatched larvae have to wait for a host to pass by or have to locate it on their own or may lay microtype eggs on the host food plants which hatch within the host gut if accidentally ingested (Mellini, 1991; Belshaw, 1993; Godfray, 1994; STIREMAN et al., 2006; WAJNBERG et al., 2007). The indirect oviposition in which females lay their eggs in places frequented by the host or on host plants is a strategy common in approximately $40 \%$ of Paleartic tachinids (BELSHAW, 1993). and provided new information on the biology of the fly Erycia furibunda (Tachinidae) and its host Euphydryas 
In the laboratory, we detailed some unknown aspects of the life-history of Erycia furibunda. It is a larval-pupal endoparasitoid and an obligate parasite; in fact, it shows a relatively long parasitic life inside the parasitized caterpillars of E. a. provincialis, allowing the host to continue living until the pupa.

Additionally, E. furibunda seems to behave not differently from many tachinids that show a developmental synchrony with the host. In tachinids the development is dependent on host hormones and the first instar larvae have to wait until the host has reached maturity or is in the pupal stage before moulting to second instar (MELLINI, 1983; LAWRENCE, 1986). In fact, the maggots of E. furibunda wait inside $E$. aurinia provincialis until it reaches the pupal stage and only when this occurs a single maggot comes out the pupa and pupates outside the host remains. This agrees with observations on many parasitic hymenopterans and dipterans whose the development of young larvae is arrested until their host pupate; the host's hormones regulate the vital step in development of the parasite (BARONIO \& SEHNAL, 1980). In line with the synchronization of the parasitoid and host life cycles, the breeding of E. furibunda and its host E. a. provincialis showed that the butterflies (not parasitized) emerge before the parasitoids and when these are at puparium. The time of puparium of E. furibunda that corresponds about to the time of phenology of butterflies and the postponed fly eclosion might show a good synchronization of the parasite lifecycle so that at the time of oviposition the host is ready to receive the eggs; this is as well as in another parasitoid of $E$. aurinia, Cotesia (=Apanteles) bignellii (Marshall, 1885), occurs (PORTER, 1983); in this species, a protracted parasitoid cocoon stage is used as a mechanism for host-parasitoid synchronisation when the host is unavailable for attack during the chrysalis, adult and egg stages.

Moreover, our results revealed a protandry of the adults of E. furibunda accordingly with the use of the hilltopping behaviour to encounter the partners adopted by several dipterans (Alcock \& KeMP, 2006; SKevington, 2008; MeI et al., 2010) including $E$. furibunda (TschorsNig, 1996). Protandry resulted both from the timing of the maggot emergence from pupa and the eclosion of the adults as observed also in other tachinids (Hebert \& Cloutier, 1988; THIÉRY et al., 2006).

Finally, we found a different incidence of the parasitoid on mortality of the caterpillars in the 2-years investigation with values of RP (4\% and $24 \%$ ) comparable to the values $(11.1 \%$ and $4.5 \%)$ reported for E. furibunda by STEFANESCU et al. (2009) in their 2-year study on the parasitoid complex attacking Euphydryas aurinia and Euphydryas desfontainii in Spain. Although the impact of natural enemies, such as parasitoids, on population size requires further research, the revealed difference in the rate of parasitism seems to be consistent with the adult population dynamics described in the past by FORD \& FORD (1930) for E. aurinia and typically affected by fluctuations, suggesting a possible role of E. furibunda as a control of population size of $E$. $a$. provincialis in Central Italy.

\section{ACKNOWLEDGMENTS}

The present study is a part of the projects of the Osservatorio per la Biodiversità del Lazio (OBL), coordinated by Prof. Valerio Sbordoni at the Department of Biology, Tor Vergata University of Rome on behalf of the Assessorato Ambiente e Cooperazione tra i Popoli della Regione Lazio and intended to provide guidelines to help monitor species protected under the Habitat Directive 92/43/CEE (Art. 17, par. 1).

We are very grateful to Dr. Pierfilippo Cerretti (University of Rome, La Sapienza) for confirming the identification of Erycia furibunda and the sexes of the individuals.

\section{REFERENCES}

Alcock J., Hemp D.J., 2006 - The Hilltopping Mating System of Leschenaultia adusta (Loew) (Dipetra: Tachinidae). - Journal of Insect Behavior, 19 (5): 645 656.

ASKeW R.R., SHAW M.R., 1986 - Parasitoid communities; their size, structure and development. In: Waage J.K. \& Greathead D. (eds.). Insects Parasitoids, 1. London Academic: 225-264.

Baronio P., Sehnal F., 1980 - Dependence of the parasitoid Gonia cinerascens on the hormones of its lepidopterous hosts. - J. Insect. Physiol., 26: 619-626.

BAUMgart E., QUicke D.L.J., SHAW M.R., 2003 - Sturmia bella (Meigen) (Dipt.: Tachinidae) and the strand that is not silk. - Entomologist's Record, 115: 127-129.

BECKAGE N.E., 1985 - Endocrine interactions between endoparasitic insects and their hosts. - Annu. Rev. Entomol., 30: 371-413.

Belshaw R.M., 1993 - Tachinid flies. Diptera: Tachinidae. - Handbooks for the Identification of British Insects, 10 [4a (i)]: 1-170.

Bulman C.R., 2001 - Conservation biology of the marsh fritillary butterfly Euphydryas aurinia. PhD thesis, University of Leeds, $155 \mathrm{pp}$. (http://etheses. whiterose.ac.uk/id/eprint/454).

CERRETti P., 2006 - Taxonomy and biogeography of west palaearctic Tachinidae (Diptera), including an interactive key to the genera and faunistic data-base. PhD Dissertation, Roma (Italy): Università di Roma La Sapienza.

CERRETTI P., 2010 - I tachinidi della fauna italiana (Diptera Tachinidae), con chiave interattiva dei generi ovestpaleartici. Volume I, Volume II + CD-ROM. Cierre Edizioni.

Cerretti P., Tschorsnig H.P., 2010 - Annotated host catalogue for the Tachinidae (Diptera) of Italy. Stuttgarter Beiträge zur Naturkunde A, 3: 305-340.

Cerretti P., Dindo M.L., Mei M., 2010 - Biologia, ecologia ed etologia. In: Cerretti P. I tachinidi della fauna italiana (Diptera Tachinidae), con chiave interattiva dei generi ovest-paleartici. Vol. I. Centro Nazionale Biodiversità Forestale - Verona. Cierre Edizioni, Verona, 573 pp. + CD-ROM.

Dindo M.L., 2011 - Tachinid parasitoids: Are they to be considered as koinobionts? - BioControl, 56: 249-255.

EHRLich P.R., HANsKi I. (eds) 2004 - On the Wings of Checkerspots: A Model System for Population Biology. Oxford University Press, Oxford, 371 pp.

FORD H.D., ForD E.B., 1930 - Fluctuation in numbers, and its influence on variation, in Melitaea aurinia, Rott. (Lepidoptera). - Ecological entomology, 78 (2): 345-352.

Ford T.H., SHAW M.R., 1991 - Host Records of Some West Palaearctic Tachinidae (Diptera). - Entomologist's Record and Journal of Variation, 103: 23-38.

FORD T.H., SHAW M.R., RoBERTSON D.M., 2000 - Further host records of some West Palaearctic Tachinidae (Diptera). - Entomologist's Record and Journal of Variation, 112: 25-36. 
Godfray H.C.J., 1994 - Parasitoids Behavioral and Evolutionary Ecology. Monographs in Behavior and Ecology. Princeton University Press, Princeton, 488 pp.

Hebert C., Cloutier C., 1988 - Seasonal biology of Winthemia fumiferanae Toth. (Diptera: Tachinidae), a larval-pupal parasitoid in the spruce budworm (Lepidoptera: Tortricidae). - Can. J. Zool., 67: 2384-2391.

Herting B., 1960 - Biologie der westpalaarktischen raupenfliegen Dipt., Tachinidae. - Monographien zur Angew. - Entomologie, 16: 1-188.

Hula V., Konvicka M., Pavlicko A., Fric Z., 2004 Marsh Fritillary (Euphydryas aurinia) in the Czech Republic: monitoring, metapopulation structure, and conservation of an endangered butterfly. - Entomologica Fennica, 15: 231-241.

KAN P., KAN B., 2015 - Biological observations on Buquetia musca (Robineau-Desvoidy) (Diptera: Tachinidae), a parasitoid of Papilio machaon Linné (Lepidoptera: Papilionidae). - Filming VarWild, Mars: 1-12.

Konvicka M., Hula V., Fric Z., 2003 - Habitat of prehibernating larvae of the endangered butterfly Euphydryas aurinia (Lepidoptera: Nymphalidae): What can be learned from vegetation composition and architecture? - Eur. J. Entomol., 100 (3): 313-322.

Kühn E., Feldmann R., Thomas J., Settele J., 2005 Studies on the ecology and conservation of butterflies in Europe. Vol.1: General Concepts and case studies. Conference Proceedings, UFZ Leipzig-Halle.

LAWRENCE P.O., 1986 - Host-parasitoid hormonal interactions: an overview. - J. Insect. Physiol., 32: 295298.

Mei M., Gibson J.F., Skevington J.H., 2010 - Observations on hilltopping in thick-headed flies (Diptera: Conopidae). - Journal of Insect Science, 10 (27): 1-15.

Mellini E., 1983 - L'ipotesi della dominazione ormonale, esercitata dagli ospiti sui parassitoidi, alla luce delle recenti scoperte nella endocrinologia degli insetti (Studi sui Ditteri Larvevoridi. XLII contributo). - Boll. Ist. Ent. "G. Grandi" Univ. Bologna, 38: 135-166.

Mellini E., 1991 - Sinossi di biologia dei Ditteri Larvevoridi (Studi sui Ditteri Larvevoridi. L contributo). Boll. Ist. Ent. 'G. Grandi”' Univ. Bologna, 45: 1-38.

Minelli A., Ruffo S., La Posta S. (eds.) (1993-1995) Checklist delle specie della Fauna italiana. Edizioni Calderini,Bologna.

New T.R., 2013 - Lepidoptera and conservation. WileyBlackwell (eds.), $280 \mathrm{pp}$.

Pape T., Richter V.A., Rivosecchi L., Rognes K., 1995 Diptera Hippoboscoidea, Oestroidea. Fascicolo 78. In: Minelli A., Ruffo S., La Posta S. (eds.). Checklist delle specie della fauna italiana. Calderini, Bologna, $36 \mathrm{pp}$.

Pennacchio F., Strand M., 2006 - Evolution of developmental strategies in parasitic Hymenoptera. Annu. Rev. Entomol., 51: 233-258.

Pinzari M., Pinzari M., Zilli A., 2010 - Deep lepidopterological exploration of Mt Cagno and surroundings (Central Italy), a restricted mountain massif and hotspot for butterfly and moth diversity (Lepidoptera). - Bollettino dell'Associazione Romana di Entomologia, 65 (1-4): 3-383.

PinZARI M., PINZARI M., SBORdoni V., 2016 - Egg laying behaviour, host plants and larval survival of Euphydryas aurinia provincialis (Lepidoptera Nymphalidae) in a Mediterranean population (Central Italy). - Boll. Soc. Entomol. Ital., 148 (3): 121-140.
PORTER K., 1981 - The population dynamics of small colonies of the butterfly Euphydryas aurinia [D. Phil. Thesis]. Oxford (UK): University of Oxford. (England).

PORTER K., 1983 - Mutivoltinism of Apanteles bignellii and the influence of weather on synchronisation with its host Eurodryas aurinia. - Entomologia Experimentalis et Applicata, 34 (2):155-162.

SFORZA R., 2003 - Candidates for the biological control of teasel, Dipsacus spp. Proceedings of the XI International Symposium on Biological Control of Weeds, Canberra, Australia, 27 April - 2 May, 2003, 155-161.

Shaw M.R., Stefanescu C., Van Nouhuys S., 2009 Parasitoids of European butterflies. In: Settele J., Shreeve T., Konvicka M., Van Dyck H. (eds), Ecology of butterflies in Europe; Cambridge University Press, Cambridge, pp. 130-155.

SINGER M.C., 2003 - Spatial and temporal patterns of checkerspot butterfly-host plant association: the diverse roles of oviposition preference. In: Boggs C.L., Watt W.B. \& Ehrlich P.R. (eds); Butterflies: Ecology and Evolution Taking Flight. Chicago Press, Chicago, pp. 207-228.

SINGER M.C., 2004 - Measurement, correlates, and importance of oviposition preference in the life of checkerspots. In: Ehrlich P.R. \& Hanski I. (eds). On the Wings of Checkerspots: A Model System for Population Biology. Oxford University Press, Oxford, pp. 112-137.

Skevington J.H., 2008 - Hilltopping. In: Capinera J.L. (ed). Encyclopedia of Entomology. Second Edition. Kluwer Academic Publisher.

Stefanescu C., Planas J., Shaw M.R., 2009 - The parasitoid complex attacking Spanish populations of Euphydryas aurinia and Euphydryas desfontainii (Lepidoptera: Nymphalidae, Melitaeini). - Journal of natural History, 43 (9-10): 553-568.

Stireman J.O., O’hara J.E., Monty Wood D., 2006 Tachinidae: Evolution, Behavior, and Ecology. - Annu. Rev. Entomol., 51: 525-555.

ThiÉRY D., Yoshida T., Guisset M., 2006 - Phytomyptera nigrina (Meigen), a parasite of first generation European grapevine moth larvae in several vineyards in the Roussillon area. - The Tachinid Times, 19: 1-4.

Tschorsnig H.P., Herting B., 1994 - Die Raupenfliegen (Diptera: Tachinidae) Mitteleuropas: Bestimmungstabellen und Angaben zur Verbeitung und Okologie der einzelnen Arten. - Stuttg. Beitr. Naturk. (A), 506: 1170.

TschORSNIG H.P., 1996 - Hilltopping Tachinidae from western Europe. - The Tachinid Times, 9: 3-4.

TSCHORSNIG H.P., ZIEGLER J., Herting B., 2003 - Tachinid flies (Diptera: Tachinidae) from the Hautes-Alpes, France. - Stuttgarter Beiträge zur Naturkunde, Serie A (Biologie), 656: 1-62.

TJøRnløV R.S., Kissling W.D. BARnagaud J., BøCHER P.K., HøYE T.T., 2014 - Oviposition site selection of an endangered butterfly at local spatial scales. - Journal of Insect Conservation, 19 (2): 377-391.

Wajnberg E., Bernstein C., Van Alphen J., 2007 Behavioral Ecology of Insect Parasitoids from Theoretical Approaches to Field Applications. - WileyBlackwell, 464 pp.

VAN NouHuYs S., HANSKI I., 2004 - Natural Enemies of Checkerspots chapter 8: 161-180. In: Ehrlich P.R., Hanski I. (eds) - On the wings of Checkerspots: a model system for population biology. Oxford University Press, Oxford, $371 \mathrm{pp}$. 
88 - Blank Page 